Historia Slavorum Occidentis

2017, nr 3 (14)

ISSN 2084-1213

DOI: $10.15804 /$ hso170304

Leszek P. SŁupecki (Rzeszów)

\title{
Dlaczego polska historiografia cierpi na obsesję korony królewskiej pierwszych Pia- stów? Różnice w postrzeganiu władzy królewskiej i jej funkcji u nowo ochrzczonych Słowian i Skandynawów. Esej
}

Słowa kluczowe: władza królewska, Piastowie, Skandynawowie

Keywords: royal power, the Piasts, the Scandinavians

Abstract: This paper looks at the ways in which the royal power functioned in newly converted Scandinavia and in the West Slavic Lands. It pinpoints the differences between them and emphasises that contrary to the general understanding, the coronations of the first three Polish kings were not symbols of sovereignty, but dependence on the Holy Roman Empire.

Ideologia królewska należy do najbardziej fascynujących tematów badawczych, który dziwnym trafem pozostaje aktualny do dziś szczególnie tam, gdzie monarchii już od dawna nie ma, ale zainteresowanie plotkami z królewskich dworów trwa w najlepsze. W zajmujących mnie czasach od schyłku starożytności (czyli gdzieś od chwili nawrócenia Konstantyna Wielkiego) aż do początku prawdziwego średniowiecza (kiedy u schyłku epoki wikingów dzicy i pogańscy Skandynawowie przestali plądrować świat, a cywilizowani i bogobojni krzyżowcy jeszcze nie zaczęli tego robić) istotę ówczesnej władzy królewskiej można spróbować opisać i objaśnić, odwołując się do wielu ważnych koncepcji teoretycznych, podkreślających najważniejsze związane z nią problemy. Jednym z najciekawszych zagadnień jest kwestia 
sakralności władzy królewskiej oraz krytyka tej tezy, a w szczególności postawionego przez Ottona Höflera problemu germańskiego „Sakralkönigtum”. Problem widzieć należy zresztą w szerszej perspektywie fundamentów wszelkiej władzy (także dzisiejszej!), które to podstawy mogą mieć charakter religijny: mityczny, kultowy, magiczny i charyzmatyczny; ale też prawny i jakoby demokratyczny (z odwołaniem się do mitycznej skądinąd idei umowy społecznej) albo wręcz posiadać wątpliwy mandat biurokratyczny, gdy władza urzędników nadana z mocy ludzi, zmienia się niepostrzeżenie w despotyczną władzę jakoby przyrodzoną, sprawowaną dlatego, że się komuś po prostu prawem kaduka należy. $\mathrm{W}$ tle problemu pojawiają się zarazem pytania o kontynuację (lub jej brak) pewnych elementów idei władzy królewskiej z pogańskiej przeszłości w czasach chrześcijaństwa (jak obecność pogańskich bogów jako przodków skądinąd już bardzo chrześcijańskich, anglosaskich królów na ich listach dynastycznych). Celowe jest więc pytanie o zachowanie ciągłości tradycji barbarzyńskich ludów mieszkających po gorszej stronie rzymskiego limesu w czasach, gdy ów jeszcze istniał i później, kiedy już razem z Rzymem upadł, choć różnice kulturowe i religijne pozostały. Nie bez znaczenia pozostaje także problem trwania w czasach kulturowego przełomu starych, pogańskich wyobrażeń o królewskiej władzy w zmieniającym się po obu stronach dawnego limesu świecie. Albowiem dawne wyobrażenia barbarzyńców o istocie władzy napotkały wówczas idee nowe, związane z jednej strony z ideologią oraz praktyką władzy rzymskiej (w całej jej złożoności: od republikańskich idei Republiki po podszytą orientalnym despotyzmem praktykę początków Bizancjum), a z drugiej strony z ideologią władzy królewskiej w Biblii (szczególnie w Starym Testamencie), a także odwołującym się do niej chrześcijaństwie z jego wspólnotową teorią i biurokratyczną, postantyczną praktyką.

Chcąc zilustrować, jak wiele wątpliwości powinniśmy mieć w głowie używając prostego zdawałoby się, lecz brzemiennego w całą masę skojarzeń pojęcia „król”, wystarczy przypomnieć, że czym innym jest korona w starożytnym Rzymie, a czym innym w średniowiecznej Francji, Anglii czy w Niemczech. To samo można powiedzieć o insygniach - także tronach i rytach intronizacji (lub szerzej: inauguracji władzy, żeby nie powiedzieć królewskiej inicjacji), regułach wyboru władcy (z odwołaniem do porządków ziemskiego i nadprzyrodzonego), o granicach władzy królewskiej, nazwach oznaczających króla (lub władcę) oraz ich wielorakich sensach i znaczeniach, wreszcie o hierarchii, a raczej hierarchiach pośród władców: antycznej, feudalnej, orientalnej (bizantyńskiej, perskiej, muzułmańskiej), barbarzyńskiej (celtyckiej, germańskiej, słowiańskiej, bałtyjskiej czy fińskiej), europejskiej lub pozauropejskiej, nie pomijając królów murzyńskich wiosek z opisów dziewiętnasto- 
wiecznych podróżników - bo niby dlaczego ich pomijać? W czym byli oni gorsi od słowiańskich, połabskich „królików” z niemieckich źródeł? Jedni i drudzy byli tylko ofiarami pewnej (a może nawet tej samej mimo upływu wieków) machiny propagandowej. Należy stawiać też pytania bardziej szczegółowe: czy wódz, jarl lub książę mógł robić to samo co czynił król? czy wypadało cesarzowi walczyć we własnej osobie jakby był zwykłym wojownikiem? czy król był w czasach pogaństwa kapłanem lub arcykapłanem rodzimej religii, a w czasach chrześcijaństwa stawał się równy biskupom w sprawach religii (skoro tak jak oni podlegał w rycie koronacji namaszczeniu). Pomińmy tu inne kwestie, np. problem całkiem licznych samozwańców, czyli władzy królewskiej legalnej i uzurpowanej (czasem bardzo skutecznie). Zauważmy wreszcie, że bywali królowie płci pięknej jak nasza Wanda (w świecie mitografii) i całkiem już realnie władająca Jadwiga, która była polskim królem, a nie królową. Bowiem królowe i księżniczki oraz ich funkcje (pamiętając również o królewskich metresach), to kolejny, zresztą bardzo ciekawy problem organizacji świata władzy.

Wśród całego wachlarza zagadnień związanych z władzą królewską na progu chrystianizacji Północnej i Środkowej Europy najbardziej intryguje mnie kwestia zupełnie innego postrzegania władzy królewskiej (ale też i jej funkcji) w nowo ochrzczonych krajach Skandynawii oraz w Polsce (do której dorzucić można by jeszcze zapewne Czechy, a także Węgry). Chodzi o stosunek władców - chciałoby się powiedzieć królów - tych krajów do własnej suwerenności i w konsekwencji pytanie o ich związki z Cesarstwem Zachodnim, czyli w ostatecznym rachunku z Niemcami. W tle, ale chyba tylko w tle, znajduje się kwestia relacji owych władców z Papiestwem i Kościołem.

W czym więc leży problem? Otóż jedna z kluczowych różnic między słowiańskimi krajami środkowej Europy tych czasów a krajami skandynawskimi polega na tym, że w pierwszych wiekach po konwersji (nie mówmy o chrystianizacji przed budową sieci parafialnej na wsi!) w najważniejszych krajach skandynawskich: Danii, Szwecji, a nawet w Norwegii panują królowie, podczas gdy w Polsce (z kilkoma wyjątkami) tylko książęta. Warto chyba zapytać - dlaczego?

Jedynym chyba badaczem, który odważył się postawić to pytanie jest Andrzej Pleszczyński, który w 2008 r. napisał: „Na obszarze Europy Karolińskiej, wraz z zachodnią Słowiańszczyzną, która stanowiła strefę wpływów politycznych Imperium, wyniesienie kogoś do rangi króla oznaczało, że posiada on mocny związek ideowy $\mathrm{z}$ monarchą frankijskim, bo w trakcie koronacji został poddany takim samym uświęcającym rytuałom, jak Karolingowie i ich sukcesorzy. Postać taka posiadała szereg cech niedostępnych władcom pogańskim, ale też i innym chrześcijańskim, jak np. we 
wczesnośredniowiecznej Skandynawii, gdzie instytucja królewska miała pogańskie pochodzenie, ale wolno zrastała się z nowymi rozwiązaniami. Władcy byli tam zawsze nazywani królami, nie używali jednak korony, ani też objęcie przez nich władzy nie wiązało się z pomazaniem. W zamian posiadali pewne cechy typowe dla przywódców formacji przedchrześcijańskich” ${ }^{1}$ I oto właśnie chodzi! Skandynawscy królowie zawsze byli nazywani królami - i przez swoich, i przez obcych, także w Cesarstwie oraz na Wyspach Brytyjskich - oczywiście jeśli tylko pochodzili z odpowiedniego rodu królewskiego (wciąż w swoisty, pogański sposób świętego), byli wystarczająco silni, by zdobyć, a także utrzymać władzę i dopełnili odpowiednich rytów (nie obejmujących jednak - powtórzmy za Pleszczyńskim - koronacji i pomazania).

Skandynawscy królowie, już chrześcijańscy, byli więc wciąż królami na sposób poniekąd pogańskimi i - co więcej - należeli do wcześniejszej rzeczywistości historycznej, bynajmniej nie średniowiecznej oraz wcale jeszcze nie minionej (o czym boleśnie przekonali się mnisi z Lindisfane i nie tylko oni). Epoka wikingów w Skandynawii jedynie współistniała z epoką wczesnego średniowiecza na kontynencie, a tak naprawdę była czymś zupełnie innym, istniejącym obok, bowiem wciąż bardzo wiele w skandynawskich obyczajach, prawach i strukturach społecznych przypominało, a przynajmniej w znacznym stopniu kontynuowało sposób życia ludów barbaricum w czasach dawniejszych, w epoce wędrówek ludów oraz wcześniejszych. Niemniej jednak skandynawscy królowie - i ci nowo ochrzczeni, i ci mniej lub bardziej chrześcijańscy od kilku pokoleń są konsekwentnie nazywani królami oraz bez cienia wątpliwości uznawani za takich przez całą Europę, co dokumentują łacińskie przekazy pisane. A polscy władcy nie! Zwróćmy jednak uwagę, że mianem królów źródła nazywają również pogańskich władców zachodniosłowiańskiej Połabszczyzny, których łacińskie źródła nie boją się określać królami (reges). Choć najczęściej próbują one obniżać ich rangę przez używanie zdrobnienia reguli („królikowie”) lub terminu subreguli, odpowiednio do potrzeb propagandowych, ustawiając ich w ten sposób w swoich opowieściach - ale jednak bez kwestionowania ich królewskiej rangi!

Także i polski (a może polański lub piastowski, wszystkie trzy przymiotniki są tu umowne) władca Mieszko I na początku swojej odnotowanej w źródłach pisanych kariery, w chwili gdy najprawdopodobniej wciąż jeszcze był poganinem, został nazwany przez saskiego kronikarza Widukinda królem (i to bez obniżającego jego rangę zdrobnienia czy prefiksu). Do jego scharakteryzowania i ustawienia we

1 A. Pleszczyński, Niemcy wobec pierwszej monarchii piastowskiej (963-1034). Narodziny stereotypu, Lublin 2008, s. 304. 
„właściwym” miejscu w szeregu wystarczyło Widukindowi podkreślenie faktu, że rządził barbarzyńcami, mieszkającymi dalej jeszcze niż ci, którzy w tym momencie korzystali z usług cesarskiego kuzyna Wichmana. Widukind nazywa Mieszka (Misaca) po prostu królem ( rex, w odpowiednim przypadku). Mówi tak o nim po raz pierwszy i ostatni w 963 lub 964 r., kiedy to został on pokonany przez Wichmana ${ }^{2}$ służącego wówczas „barbarzyńcom” (jak Widukind określa w tym kontekście Wolinian i/lub Wieletów). Jak wszyscy pamiętamy Wichman walcząc wespół z owymi barbarzyńcami Misacam regem, cuius potestatis erant Slavi qui dicuntur Licicaviki, duabus vicibus superavit fratremque ipsius interfecit, predam magnam ab eo extorsit ${ }^{3}$. Nie wchodząc w ważne skądinąd zawiłości interpretacji szczegółów owego otwierającego pisemne dzieje Polski wydarzenia ${ }^{4}$, warto zwrócić uwagę na fakt, który nie wiedzieć czemu najczęściej się pomija. Otóż Mieszko występuje w tej wzmiance jako król! Niemniej już w następnej (i ostatniej) zapisce o Mieszku u Widukinda z 967 r. ranga piastowskiego władcy nie jest już w ogóle wspomniana, a jego pozycję ilustruje dyskutowane często określenie, nazywające go „przyjacielem cesarza” (amicus imperatoris $)^{5}$. Kolejne źródła określają Mieszka różnymi już terminami, włącznie ze szczególnie interesującym nazwaniem go margrabią (marchio) i bardziej banalnym uznaniem za księcia $(d u x)$ - nigdy już jednak więcej nie został Mieszko I w łacińskich źródłach nazwany królem! Dlatego w polskiej szkole wmawia się biednym dzieciom, że królem nie był, choć jego portret widnieje we wszystkich pocztach królów polskich (także tych, które zdobiły okładki zeszytów do historii). Kolejni trzej polscy królowie uznani za granicą za takich, to jak wszyscy pamiętamy Bolesław Chrobry, Mieszko II i Bolesław Śmiały. W przypadku każdego z nich mamy do czynienia z problemami związanymi z koronacją lub z koronacją i zegnaniem $\mathrm{z}$ tronu oraz z różnymi interpretacjami tych wydarzeń wówczas i dziś. Zarazem (przynajmniej dla mnie) coś jest wyraźnie dziwnego w owych naszych współczesnych interpretacjach owych faktów koronacji, w których najczęściej chcemy widzieć przejaw

2 Szczegóły i tło owych wydarzeń były w polskiej literaturze historycznej analizowane wystarczająco dobrze, często i intensywnie, by trzeba tu było odwoływać się do literatury.

3 Widukindi rerum gestarum Saxonicarum libri tres, wyd. G.Weitz, [w:] MGH SRG, Hannoverae 1882, lib. III, cap. 66, s. 81.

4 Odniosłem się do nich przy okazji rocznicy chrztu Polski w jednym z artykułów, zob. L. Słupecki, "Chrzest Polski” i kilka związanych z nim problemów, [w: ] Tyś z nami związat się przez Chrzest. 1050 rocznica Chrztu Polski. Podkarpacie, red. ks. S. Nabywaniec, A. Pęzioł, Rzeszów 2017, s. 15-30.

5 Widukindi rerum gestarum, lib. III, cap. 68-70, s. 81-84. 
suwerenności państwowej i swoistej dojrzałości polskiej władzy królewskiej. Może więc powinniśmy spojrzeć na problem porównawczo od innej strony i z odmiennej perspektywy np. skandynawskiej?

Co wiemy o koronacjach królów skandynawskich? Jenny Jochens podsumowała problem w encyclopedycznym skrócie: „During the $12^{\text {th }}$ century German emperors in turns employs similar [jak koronacje na kontynencie] ceremonies as means of controlling Danish kings and subkings on whom they conferred crowns in return of oaths of obedience" ${ }^{6}$. Jako pierwszy taki król podporządkowany Cesarstwu, pojawia się zdaniem Jenny Jochens Kanut Laward (+1131 r.) zwany jako duński książę dux Daciae, który dzięki cesarzowi Lotharowi III został królem, lecz u Obodrytów, związanych bardzo ściśle z Duńczykami, ale jednak Słowian. Po śmierci Kanuta Lawarda (został on zamordowany) Lothar III doprowadził do koronacji Magnusa Nielsona w 1134 r. (regio more coronatus). Przy tej okazji Magnus niósł przed cesarzem miecz (szczegól, który pojawia się w opisie wielu spotkań polskich władców z niemieckimi cesarzami). Wreszcie podczas wojny domowej w Danii Sven Grathe został koronowany przez Fryderyka Barbarossę w 1152 r. - i on również niósł wówczas miecz przed cesarzem ${ }^{7}$. Pierwsza koronacja „kościelna”, nie związana z niemieckimi próbami narzucenia dominacji miała miejsce w Skandynawii, gdy w Norwegii w 1163 r. (lub w 1164) Magnus Erlingson został ukoronowany przez arcybiskupa Eysteinn Erlandsona podczas próby uśmierzenia wojny domowej. W Danii nie związana z niemieckimi próbami dominacji koronacja „kościelna” dokonała się po raz pierwszy w Ringsted w 1170 r., gdzie koronował się Waldemar I Wielki - i przy tej okazji próbował zabezpieczyć prawa do tronu dla swojej linii rodu koronując wraz z sobą syna Kanuta. Tyle wiadomości encyklopedycznych. Pozostaje pytanie czy już dużo wcześniej Kanut Wielki mógł być ukoronowany jako król Anglii? Jakub Morawiec, autor nowej polskiej biografii Kanuta stwierdza, że dokonało się to zapewne w 1017 r. - nie wchodząc bliżej w szczegóły ${ }^{8}$. Sprawa pozostaje bowiem niejasna, choć biografowie Kanuta Wielkiego zauważają problem.

Po takim skrótowym przedstawieniu kwestii koronacji skandynawskich królów (jak od razu widać nie jest to dla skandynawskiej historiografii kluczowy problem badawczy), czas wrócić od kwestii koronacji u Słowian Zachodnich i do spojrze-

6 J. Jochens, Coronation, [w: ] Medieval Scandinavia. An Encyclopedia, wyd. Ph. Pulsiano, K. Wolf, New York, London (Routledge) 1993, s. 108.

7 P. Beskov, Kröning, [w:] Kulturhistorisk Lexikon för nordisk medeltid, t. 9, Malmö 1964, s. 498-502 .

8 J. Morawiec, Knut Wielki, król Anglii, Danii i Norwegii (ok. 995-1035), Kraków 2013, s. 124. 
nia historiografii polskiej na to zagadnienie. Nie wdając się w szczegóły stwierdzić można, że intensywność i tenor dyskusji tego zagadnienia wydają się wskazywać, iż kwestia korony przedstawiana jest jako jedno z kluczowych zagadnień symbolizujących państwową suwerenność w czasach początków narodowej historii. Nie chcę być psychoanalitykiem polskiej historiografii, ale w upraszczającym zawiłości skrócie sprawa zdaje się wyglądać następująco. Tak mianowicie, że idealna sytuacja dla Polski i jej władcy byłaby zdaniem wielu polskich mediewistów wtedy, gdy na czele państwa stałby król, oczywiście ukoronowany oraz namaszczony, uznawany za króla przez cesarza i papieża, którzy w ten sposób sankcjonowaliby suwerenność Polski, a także jej przynależność do szlachetnej rodziny cywilizowanych, chrześcijańskich nacji europejskich. Nie chcę być historykiem historiografii, ale jeśli mam rację, to mamy tu do czynienia z przejawem pewnego rodzaju postkolonialnego, europejskiego kompleksu. Jeśli bowiem porównamy ten postulowany stan idealny ze wszystkim, co wiemy o koronacjach skandynawskich to widać jasno, że jest to absurd. Fakt koronacji z cesarską (a najlepiej i papieską) zgodą oraz błogosławieństwem oznacza bowiem coś dokładnie przeciwnego. A mianowicie wejście w sytuację pewnego rodzaju szlachetnej - ale jednak - podległości cesarzowi. Wystarczy spojrzeć na mocno dyskutowaną niedawno miniaturę przedstawiającą cesarza, dwóch królów, a także niższych rangą przedstawicieli elity, na której Johannes Fried dostrzegł wyobrażenie Ottona III, Bolesława Chrobrego i Stefana I ${ }^{9}$. Jeśli nawet nie wszyscy zgodzą się z interpretacją Frieda, kim są królowie na obrazku i co z tego wynika, to nie podlega dyskusji, kto ma na nim wyższą a kto niższą rangę i że miniatura przedstawia system zależności. Ta miniatura z epoki wygląda nieomal jak ilustracja pokazująca drabinę feudalną w dobrym podręczniku szkolnym z dawnych czasów, gdy w szkole uczono jeszcze podstaw historii średniowiecza. Warto odwołać się tu też do umykającego uwadze badaczy stwierdzenia Brunona z Kwerfurtu z jego listu do Henryka II, gdzie Bruno ubolewa, że Henryk pozostaje w konflikcie z Bolesławem Chrobrym, tymczasem lepiej by było talem hominem habere fidelem, cuius auxilio et consilio tributum accipere... ${ }^{10}$. Trudno o jaśniejsze przedstawienie o co chodzi w kategoriach feudalnych stosunków seniora z wasalem (wspomniany fidelis), który służy seniorowi świadcząc mu consilium et auxilium.

9 J. Fried, Otto III und Boleslaw Chrobry: Das Widmungsbild des Aachener Evangeliars, der „Akt von Gnesen" und das frühe polnische und ungarische Königtums, Stuttgart 2001.

10 Epsitola Brunonis ad Henricum regem, [w: ] MPH sn, t. IV, cz. 3, wyd. J. Karwasińska, Warszawa 1973 , s. 102. 
Rodzi się tu pytanie, dlaczego to mianowicie polscy (a także czescy i węgierscy) władcy zgodzili się wejść w taki oto system zależności - wczesnofeudalny, post-rzymski i zachodnioeuropejski (frankijski, karoliński czy ottoński, mniejsza jak go nazwać) z cesarzem na szczycie hierarchii, natomiast władcy skandynawscy nie. Wydawałoby się, że trzymanie się dawnego (w swoich korzeniach pogańskiego) modelu władzy królewskiej, pozwalało zachować większą suwerenność i niezależność. I chyba faktycznie tak właśnie w Skandynawii było! Tam jednak korzenie królewskiej władzy wydają się dużo starsze, a tradycje związanych z nimi wspólnot bardzo dawne, jak choćby w Uppsali czy Lejre. Tego u Słowian Zachodnich wyraźnie brakuje. Zarazem jednak zaakceptowanie owego nowego systemu pozwalało wejść szybko w ramy szerokiej sieci powiązań, oczywiście z pewnym uszczerbkiem dla własnej rangi i suwerenności, ale też chyba z istotnymi profitami dla władców (i ich rodów oraz elit ich państw). Pójście taką drogą kosztowało sporo - trzeba się było zgodzić nie tylko na chrzest i zmianę wiary (to akurat Skandynawowie też zrobili), ale także zaakceptować reguly hierarchii obowiązujące $\mathrm{w}$ takim imperialnym systemie, włącznie z własną podległą w nim oraz osłabioną pozycją. Nie można było bowiem już tak po prostu, w zgodzie z własnym dawnym obyczajem, cieszyć się rangą królewską, lecz trzeba było o nią zabiegać. A przed jej uzyskaniem uznawać własną, niższą od królewskiej pozycję w owej sieci zależności, zabiegać o łaski, negocjować i wzmacniać swoje w niej miejsce. Należało więc robić dokładnie to samo, co inni uczestnicy tej samej gry i beneficjenci tego samego systemu. Wydaje się, że władcy zachodniosłowiańscy zgodzili się na takie reguły, natomiast władcy skandynawscy (znający bardzo dobrze pozostającą poza takim systemem Anglię!) - najwyraźniej nie. Poza systemem pozostała także wciąż jeszcze bardzo skandynawska i od samego początku spoglądająca w stronę Bizancjum Ruś. Nie przypadkowo Włodzimierz Wielki jest dla Thietmara bezspornie królem (rex Ruscorum) ${ }^{11}$, podczas gdy nasz Bolesław Chrobry w tym samym rozdziale jego kroniki nazywany jest jedynie swoim własnym imieniem i bez określenia rangi ${ }^{12}$.

Poruszony tu problem wymaga z pewnością szerszych i bardziej pogłębionych badań, w które w tym tekście już jednak wchodzić nie będę. Wydaje mi się wszakże, że - jeśli moje porównanie ze Skandynawią jest uprawnione - to trudno uznawać

11 Thietmari Merseburgensis episcopi Chronicon, wyd. R.Holtzmann, [w:] MGH SRG s. n. IX, Berlin 1935, lib. VIII, cap. 31, s. 528-529.

12 Czyli bez uwzględnienia jego ewentualnej koronacji na zjeździe gnieźnieńskim w $1000 \mathrm{r}$. Nie można mieć jednak do Thietmara pretensji o to, że nie czytał monografii Johanesa Frieda, patrz powyżej, przyp. 9 . 
pierwsze koronacje piastowskich królów za dowód ich suwerenności. Było chyba dokładnie odwrotnie. Świadczyły one raczej o ich wysiłkach, żeby w imperialnej sieci władzy zająć jak najlepsze, ale bynajmniej nie suwerenne miejsce. Dlatego wolę zajmować się badaniami nad pogańską Skandynawią w epoce wikingów. Ci bowiem zajmowali należne sobie miejsca ciekawszymi metodami, a co wtedy Normanowie (a potem ich potomkowie) myśleli o europejskiej hierarchii feudalnej, ilustruje piękną anegdota Dudona z St Quentin o tym, jak Rollo (kronikę u Dudona zamówił wnuk Rollona) po swoim chrzcie potraktował króla Karola Prostaka, gdy zażądano, aby ucałował jego stopy. Rollo dumnie odmówił, stwierdzając, że nigdy nie będzie przed nikim klęczal. Namówiony przez Franków zgodził się jednak, żeby królewską stopę ucałował jeden z jego wojowników. Ten nie schylając się przesadnie uniósł królewską stopę do swoich ust, sprowadzając króla całkiem dosłownie na ziemię, bowiem król oczywiście upadł do tyłu, co wszystkich przyglądających się temu swoistemu hołdowi lennemu doprowadziło do ataku śmiechu ${ }^{13}$. A Normandia pozostała we władzy Rollona i jego wikingów. Właśnie dlatego Wilhelm Zdobywca zdobył potem Anglię, a Bolesław Chrobry nie zdobył Niemiec.

Nadesłany: 5 V 2017

Nadesłany po poprawkach recenzyjnych: 12 IX 2017

Zaakceptowany: 18 IX 2017

prof. dr hab. LesZEK P. SŁUPECKI

leszek.slupecki@interia.pl

Why is Polish historiography obsessed with the idea of royal coronations of the first Piast rulers? An essay on differences in the perception of royal power and its function in newly converted West-Slavic Lands and Scandinavia

This paper analyses the difference in the perception, definition and usage of the concept of royal ideology in the tenth-eleventh-century Poland and Bohemia (or among Western

13 Dudonis Decani S. Quintini, De Gestis Normanniae ducum libri tres, II, 29, [w: Patrologia Latina, wyd. J.P. Migne, t. 141, Parisii 1853, s. 650-651; O Dudonie oraz zderzeniu obyczajów frankijskich i wikińskich patrz w: W. Fałkowski, Frankijskie rytualy w normańskim świecie. Przenikanie wzorców i fenomen akulturacji, Roczniki Historyczne LXXIV (2008), s. 7-30 (o „hołdzie” Rollona patrz s. 22). 
Slavs in general) versus Scandinavia. It demonstrates that while Polish (and Czech) rulers agreed to follow Carolingian ('Frankish') model of royal power, the old pagan model of rulership preserved in Scandinavia seemed to secure more power for the king, including the truly royal title. The paper proposes that the West Slavic elites decide to enter the imperial system of Western Europe in an attempt to act as external members of the Christian and Imperial world, but instead they had to accept a new religion, rules, hierarchy and their own subordinate position. Hence, contrary to the general understanding, the coronations of the first three Polish kings were not symbols of sovereignty, but rather of dependence on the Holy Roman Empire.

Translated by: Leszek P. Stupecki 